\title{
Erce and Other Possibly Keltic Elements in the Old English Charm for Unfruitful Land*
}

\author{
AUDREY R. DUCKERT
}

$\prod_{H}$

HE FOCAL PROBLEM of this discussion of the charm for unfruitful land is the identity of Erce, a name or word repeated three times at the beginning of the second metrical prayer. Whether Erce is the name of a goddess (and if so, of what nature), a verb form, or an incantation has long been debated. Specifically Irish elements in other charms have been cited by Howard Meroney; ${ }^{1}$ and it is a Keltic case that $I$ wish to argue here, reexamining the charm in the light of its Keltic elements and analogs, especially those noted in the folklore-motif indexes of Stith Thompson ${ }^{2}$ and Tom Peete Cross $^{3}$ which have appeared since the last printed discussions about Erce.

The charm, which Dobbie designates "For Unfruitful Land" exists in only one known manuscript (Cotton Caligula A vii). ${ }^{4}$ It is written in an eleventh century hand and seems to have been bound with the Old Saxon Heliand manuscript sometime in the early seventeenth century, thus not in company with any other works of Old English poetry. It is a mixture of prose "recipes" and metrical prayers to be used in restoring fertility to land that may have been bewitched or will not yield well. For all its fascination, it is scarcely great poetry; its language is as mixed as its meters, and includes Keltic loanwords and church Latin as well as the basic Old English.

* The Anglo-Saxon Poetic Records stand as the best possible monument to their editors, George Philip Krapp and Elliott Van Kirk Dobbie. Fastidious, elegant, exemplary of the art and craft of the dedicated scholar, they have already furnished more than a generation of students of Old English with reliable text and thorough, concise notes. It is now 30 years since Professor Dobbie wrote the preface for the last of the six volumes of the Records, The Anglo-Saxon Minor Poems (New York: Columbia University Press, 1942), which includes the charm for unfruitful land (pp. 116-118) that is the subject of this article; except for addition to the bibliography, the edition stands. What more is there to say?

1 Howard Meroney, "Irish in the Old English Charms," Speculum, XX (1945), 172-182.

2 Stith Thompson, Motif-Index of Folk Literature, rev. ed., 6 vols. (Bloomington: Indiana University Press, 1956), passim.

3 Tom Peete Cross, Motif-Index of Early Irish Literature, Indiana University Publications, Folklore Series, no. 7 (Bloomington: Indiana University Press, 1952), passim.

4 A literal translation of the charm, with the $\mathrm{OE}$ text on facing pages and following discussion, is to be found in Godfrid Storms, Anglo-Saxon Magic (The Hague: Martinus Nijhoff, 1948), pp. 172-186. 
The traditional assumption, which there seems no reason to challenge, is that the charm is an adaptation of a pagan rite to something the Church could live with - a form of ecumenism which in early England might well involve at least vestiges of Keltic traditions established well before the adventus saxonum. Considering what is known and knowable about languages much further back in time, it seems almost incredible that our knowledge of Brittonic is based chiefly on inscriptions and evidence from place-names, but this is so. There are no known literary monuments in either the oral or written tradition. In this situation it seems reasonable to adduce analogs from other Keltic sources. Irish is particularly helpful and likely here, since we know of considerable and continuous contact, especially through the monasteries.

Specific lexical evidence on Keltic loanwords and cognates will be summarized at the end. Much of it is well-travelled philological territory; apparently unexplored are a number of analogs in the traditions themselves. Following is a brief tour through the charm with notations from the Tom Peete Cross Motif-Index of Early Irish Literature, which was correlated to the first edition of the Thompson Motif-Index and cited in the second edition. (If Old English scholars have not made wide use of these works, there is some reciprocity, for I find no citations in either Thompson or Cross for the charms.)

Charm is indeed the most appropriate descriptive for this combined blessing and exorcism. It covers all fronts : witchcraft, pagan religion, and presumably the Christian religion adapted to the time and place. It begins with "Here is the remedy..." offering help if the land will not produce good crops or if any harm has been done to it by magic or witchcraft. Nowhere in the charm or in attendant OE lore is there any hint as to how the land got that way. Cross cites from Irish sources ${ }^{5}$ : land made magically sterile; druid's curse makes land magically sterile; magic poem (satire) does likewise. A dragon's shriek, a broken tabu, the owner's wickedness, and even magic swine can sterilize land.

It can be made fruitful by a magic object, a magic song, or the sign of the cross. The OE charm calls for the removal of four sods from the land before dawn, and their removal to a church where the green sides are to be faced toward the altar. Cross cites magic sod - and for magic we may read holy and vice versa - and in detail: magic sod indicates falsehood by turning grassy surface downward, truth by turning it upward. This

5 It would be singularly inappropriate to turn a tribute to as lively a scholar as Elliott Van Kirk Dobbie into a catalog of motif-index numbers. He would have read through them, but with justifiable impatience. Since the Thompson and Cross motif-indexes are themselves well indexed, words, rather than cues such as D 1563.5 will be used here to relate Irish analogs to pertinent elements in the charm. 
may suggest a kind of reverse magic to undo the spell, since the charm specifies the green side to be turned to the altar.

Honey and yeast and milk are called for; Cross cites all of these and even, extravagantly, the "milk of a hornless, single-colored cow drunk by man to make wife fruitful." Next, take part of every kind of tree growing on the land except hardwoods. Acceptable and nonacceptable woods are folklore commonplaces, and all kinds of trees - mostly deciduous ones - have been accused of providing the wood for the True Cross. There is an Irish reference to the cross being made of four kinds of wood, but nothing more specific. Next, take "part of every nameknown herb except glappan" which Magoun, with a question mark, renders as "buckbean" and Storms calls "burdock"; we are probably never going to find out. The necessity for knowing right names in order to work magic is also commonplace.

The "mass-priest" is then to sing four masses over the sods, and whether this means four masses over each or four over the four is not clear. There are Irish analogs for four as a magic number, but also for three, five, seven, nine, and so on. All numbers seem to be potentially magic in one way or another. The sods are to be returned to their original location before the sun goes down, and in the bottom of the hole where they were dug, four crosses fashioned of quick beam (OE cwicbeame) are to be placed. This tree is generally equated with the quaking aspen, but one might also consider Elizabeth Mary Wright's report of quicken and wicken as general English dialect use for the mountain ash or rowan tree, well-known for its magic powers. ${ }^{6}$ The crosses are then to be named in Latin: "crux Matheus, crux Marcus, crux Lucas, and crux Sanctus Johannes" exhibiting an ancient device in oral literature, including Greek and Sanskrit, in which four names appear in a series with the last preceded by an adjective.

Then comes the first metrical prayer, in which the exorcist/magician - it is not certain who - is told to say, after turning to the east, "Eastward I stand and pray for favors ...." Cross cites an Irish prayer with face toward the east from a Life of Columcille. This sixth century Irish saint, perhaps better known as Saint Columba, founded the monastery on the Holy Isle of Iona, from which Aidan was to go in the next century to found the island monastery at Lindisfarne. ${ }^{7}$ The prayer continues in a pagan-Christian ambivalence, asking heaven and Mary that the Lord may help [me] get this spell (OE gealdor) through [my] teeth. At the end, "Turn yourself three times in the direction of the sun ...," Cross cites

${ }^{6}$ Elizabeth Mary Wright, Rustic Speech and Folklore (London: Oxford University Press, 1913), p. 234.

7 Further discussion of this and also of other Irish analogs and influences in Old English literature, specifically in The Wife's Lament and The Seafarer, may be found, passim, in Gareth W. Dunleavy, Colum's Other Island (Madison: University of Wisconsin Press, 1960). 
Irish instances of magic power by circumambulation dextrorsum, i.e. sunwise, for good luck.

There follow Christian rituals, singing of Benedicte, Magnificat, and Pater noster, prayers to Christ, Mary, and the cross - again the broad spectrum - and then "when all that is done" take unknown seed from beggars and give them back twice as much as you received. Then gather together all the plow-tackle (Cross cites a magic plow in the Life of Columcille) and place in a hole bored in the plow-tail incense, fennel, holy soap, and holy salt. The soap and salt have been much speculated upon; Cross cites Irish analogs for magic salt, which Magoun ${ }^{8}$ identifies as more general; the soap remains a mystery in this context, though Thompson cites magic soap giving clairvoyance and making fairies visible. The seed is then to be placed in the plow and the second metrical prayer begins: "Erce, Erce, Erce, eorban modor ..." ("Erce, Erce, Erce, mother of earth"). Dobbie's notes on Erce ${ }^{9}$ ably summarize the scholarship on the word up to the date of his edition. Her identification as a Germanic fertility goddess goes back to the fourth edition of Jacob Grimm's Deutsche Mythologie:

Can there lie disguised in erce a proper name ERCE gen. ERCAN connected with the Old High German adjective ërchan, simplex, genuinus, germanus? It would surely be more correct to write Eorce. Ought it to suggest the lady Erche, Herkja, Herche, Helche renowned in our heroic legend? The distant traces in Low Saxon districts of a divine dame Herke or Harke by name are significant. ${ }^{10}$

This frenzied passage appears to be the wellspring of Erce's identification as a German goddess. She is further said to fly through the countryside between Christmas and Twelfth Day, distributing [unspecified] gifts, but she will soil or scratch the distaffs of maids who have not yet finished spinning their flax. Dobbie quotes both De Vries and Grendon as being more cautious, the latter viewing it as an incantatory phrase, "the meaning of which, if it ever had any, has been lost." ${ }^{11}$ It may well be. Certainly, "Herke" is not a major Germanic goddess. Johannes Hoops' Reallexikon" has an entry at Erce, citing the OE line and Grimm, and positing a connection with "Frau Harke" and ero "the earth" but ending with the telling sentence: "Die Ableitung bleibt dunkel." If one who knew Germanic antiquity as well as Hoops felt the ground was shaky, chances are it is.

8 F. P. Magoun, Jr., "Zu den æ. Zaubersprüchen", Herrigs Archiv, CLXXI (1937), pp. 24-25.

9 Dobbie, op. cit., p. 208.

${ }_{10}$ Jacob Grimm, Teutonic Mythology, 4th ed., trans. James Stallybrass (1883; rept. New York: Dover, 1966), p. 1364.

11 Dobbie, op. cit., p. 208.

12 Johannes Hoops, Reallexikon der Germanischen Altertumskunde (Strassburg: Karl J. Trübner, 1911-13), vol. 1, p. 625. 
Meroney ${ }^{13}$ cites previous attempts to relate Erce to a possibly Keltic word in one of the OE Leechdoms which, in the four versions he cites, appears variously as acræ, ærcræ, acre, arcre, earcre, and encrcre in the opening lines of the charm. Grattan and Singer ${ }^{14}$ declare these same words "gibberish," and gibberish they may well be. The same might be said for "Hickory dickory dock," but when Elizabeth Mary Wright ${ }^{15}$ cites Keltic numerals used in the Lake District for counting sheep: yan, tyan, tethera, methera, pimp, sethera, lethera, HOVERA, DOVERA, DICK, another possibility emerges, strengthened by the association of clocks and numbers.

In this context, with no dramatic proof, but in hope of shedding some light, I offer the following speculations about a Keltic Erce.

First, that Erce may be a verb-form and not a name at all. Lewis and Pedersen ${ }^{16}$ cite Old Welsh erchim, Modern Welsh erchi: archaf "I bid, ask"; arco, arcu "I beseech" with numerous cognates, e.g. Cornish arghaf, erghys, and Middle Welsh erchis, erchi - all forms of the verb "to beseech," an entirely appropriate beginning for a prayer.

Second, phonetically plausible Keltic forms cited in Pokorny ${ }^{17}$ fall into an appropriate semantic domain: Old Irish air-icc "to find," arg "[rain] drop"; Middle Irish airim "plow," ar "farmland," a(i)rech "concubine"; Gaulish are "beside, in front, to the east" also evidenced in place-names Are-morica and Are-brigium. Pokorny also cites Cornish and Breton forms as well as those already noted from Lewis and Pedersen. Tenuous as these connections are, they are at least as likely as Frau Harke.

Third, Erce may indeed be a name, but of Keltic rather than Germanic origin. Thurneysen, ${ }^{18}$ drawing most of his material from Macalister's Studies in Irish Epigraphy, notes several names from inscriptions, e.g. ERCAIDANA, HERCAITH, MAQIERCIAS, MAQQIERCCIA. The maqis an early form of the Gaelic patronymic; Erc is cited as a masculine nominative singular - a man's name, with the probable meaning "spotted or dark red cow." Possibly; but a man's name embodying such an obviously female concept seems odd in a culture where he-man names such as Fergus flourished.

13 Meroney, op. cit., p. 176.

14 J. H. G. Grattan and Charles Singer, Anglo-Saxon Magic and Medicine (London: Oxford University Press, 1952), p. 125, n. 5 .

15 Wright, op. cit., p. 327.

16 Henry Lewis and Holger Pedersen, A Concise Comparative Celtic Grammar (Göttingen: Vandenhoeck and Ruprecht, 1937), pp. 108, 339, et passim.

17 Julius Pokorny, Indogermanisches Etymologisches Wörterbuch (Bern: Francke Verlag, 1959), Vol. 1. [translations mine].

18 Rudolf Thurneysen, A Grammar of Old Irish, rev. and enlarged ed., trans. D. A. Binchy and Osborn Bergin (Dublin: Institute for Advanced Studies, 1946), pp. 59, 188, et passim. 
Historians with a very nationalistic orientation must be taken less earnestly than inscriptional and manuscript evidence; they are a mixed blessing because they tantalize but do not always authenticate. It would, however, be a pity not to note some possible evidence from them. Eugene $0^{\prime}$ Curry's lectures, delivered in $1855-56^{19}$ go on at length about an apparently male Erc and his sister Acaill or Acall. The verses he quotes - presumably the translation is his - end with "The six best women in the world were / After Mary the Mother [of God] / Medhbdh, Sadhbdh, fair Sairaid, Faind / Erc, Emer, and Acall." I count seven, not six; and Erc is neither first nor last. The source may be suspect. O'Curry's index has two blind references to Erc and Erca.

P. W. Joyce ${ }^{20}$ names three apparently different male Ercs; he also notes Erca, Saint Patrick's embroideress, and Ercnait, embroideress to Saint Columkille. Two highly respected contemporary scholars in the field, Myles Dillon and Nora K. Chadwick, cite a male Erc from the text (ninth century) of the Tripartite Life of Saint Patrick as ruling the kingdom of Dál Riata on the northeast coast of County Antrim. ${ }^{21}$

Clearly, there is nothing in the foregoing to establish an Irish earth or fertility goddess with a name like Erce, but a form of the name was clearly in use in Ireland at an appropriate time and was familiar to at least two saints known to have had contact with the English. No analogs have been adduced from sources in Old English or from later English tradition; thus the continental "Frau Herke" becomes more remote.

After the "mother of earth" is addressed, the prayer asks that she be granted success with specific grain crops, and then that the Lord and the saints grant him (unspecified but presumably the land-owner?) that the crops be safe against witchcraft, and further that no woman know the words nor any man have sufficient power to undo the words just said. There follows a prayer, beginning, "Hal wes pu, folde, fira modor ..." ("Hail be thou, earth, mother of men"). Then flour of every kind is to be baked into a loaf of bread the size of the palm of the hand, kneaded with milk and holy water, and placed under the first furrow. The seven-line prayer that follows and the brief benediction appear to be completely Christian. "[Say] pater noster three times" is the last command.

Keltic loanwords are rare in Old English; yet in the 82 lines of this charm there are three words that are almost certainly loans and an addi-

19 Eugene O'Curry, Lectures on the Manuscript Materials of Ancient Irish History (1860; re-issue Dublin: W. B. Kelly, 1873), esp. pp. 513-515.

${ }_{20}$ P. W. Joyce, A Social History of Ancient Ireland, Vol. 2, 2d ed., (Dublin: M. H. Gill and Son, 1913), pp. 87, 133, 366, 490, 539.

${ }^{21}$ Myles Dillon and Nora K. Chadwick, The Celtic Realms (New York: The New American Library, 1967), p. 69. 
tional six for which both Keltic and Germanic forms are known. ${ }^{22}$ One of these, cited above in its OE genitive plural form fira "of men" occurs twice; the second time it is firum, a dative plural; the Keltic form is fer "man."

The three apparently Keltic words are

1) $d r y$ "sorcery" (1.3) from Old Irish drui "druid" with complete phonetic transfer from the Irish, the $-y$ - a product of umlaut.

2) stór "incense" (1. 48). Max Förster ${ }^{23}$ makes a case that is both phonologically and psychologically convincing, even if he is on ground admittedly tentative. Opposing the customary assumption that the word was taken from Latin storax and then lost its ending, he suggests, reasonably, that this was probably not a household word, that it would not be known to the laity, and therefore would tend to retain the ending; he also gives examples of instances in which the - $k$-suffix has been tolerated and retained in the underground, substratum vocabulary that English has inherited from Latin. If this be Latin, why not here? Förster's argument is complicated; briefly, his theory is that $\mathrm{OE}$ stór is a nominative based on Vulgar Latin storacem shaped into Irish. Modern Welsh ystor "incense," showing the prothetic vowel, is probably also a loanword from Old Irish *stór, according to Förster.

3) trumme (1.33), cited by Holthausen as a possibility; he mentions Old Irish dron "firm" and offers no Germanic cognates.

In addition to fir, five other words in the charm show both Keltic and Germanic faces:

1) lyb-, the first element in lyblace "witchcraft" $(1.3 ; 1.63)$ has Germanic cognates, but Old Irish luib "herb, plant" should be noted.

2) meolc "milk" (1.6) is most probably Germanic, but Old Irish has melg with the same meaning.

3) treow "tree" (1.6), for which Holthausen cites Old Irish daur and dair as cognates.

4) drype (1.9), not convincing, but Holthausen cites possible Germanic forms and ? Old Irish drucht $<*$ druft $<*$ drupt.

5) arim "say" [?] (1.40): according to Holthausen, OHG rimen and OIr do-rimu are both possible sources; Thurneysen and also Lewis and Pedersen note a verb ad-rimu "to reckon" as well. The prothetic vowel, otherwise problematical, would be neatly explained by accepting this as a Keltic loanword.

22 F. Holthausen, Altenglisches etymologisches Wörterbuch (Heidelberg: Carl Winter, 1934), passim. [translations mine].

${ }^{23}$ Max Förster, "Altenglisch stór, ein Altirisches Lehnwort", Englische Studien, LXX (1935-36), pp. 49-54. [translations mine]. 
There is clearly an undercurrent of Keltic or possibly Keltic loanwords in this charm against unfruitful land. There is also very obvious Latin imposed on the Old English fabric. The broad-spectrum coverage is clear again in lines 10-12 where the Latin imperatives, crescite, multiplicamini, replete are carefully glossed with $\mathrm{OE}$ wexe, gemænigfealda, and gefylle. It is indeed possible that this may have been a trilingual ritual at some time, carefully constructed to satisfy pagan and Christian without offense to either.

There it is: an obvious mixture, a puzzle that will endure as long as men think about it. But as R. H. Hodgkin wisely remarked, "These are questions to be remembered, even though we shall never know the answers."

University of Massachusetts

\section{SPECIAL ISSUE IN 1973}

A commemorative issue of Names, in honor of the late Professor Kemp Malone, philologist, world authority on Chaucer, and life-member of the American Name Society, is being planned for publication in 1973. Articles are now being solicited by the special editor for the issue, Professor Thos. Pyles, 629 Boulevard, Gainesville, Florida 32601, to whom all enquiries should be addressed. As an incentive to younger writers and students of onomatology, a $\$ 100$ cash prize will be offered for the most outstanding article submitted by a scholar under 30 . Deadline for all contributions is December 31, 1972. 